\title{
Demographic Profile of HIV Sero Positive Clients Attending Integrated Counseling and Testing Centre, Mumbai, India
}

Nayana Ingole*, Supriya Paranjpe, Purva Sarkate, Ujwala Kawane, Mukti Mody, Sameer Shinde and Preeti Mehta

Department of Microbiology, Seth G. S. Medical College and KEM Hospital, Mumbai

*Corresponding author: Nayana Ingole, Department of Microbiology, $5^{\text {th }}$ floor, Multi-Storey Building, Seth G. S. Medical College and K. E. M. Hospital, Parel, Mumbai 400 012, India, Tel: 091-22-24107825; Fax: 091 -22- 24164372; E-mail: nayanaingole@gmail.com

Received date: June 02, 2014, Accepted date: October 29, 2014, Published date: November 08, 2014

Copyright: ( 2014 Ingole N, et al. This is an open-access article distributed under the terms of the Creative Commons Attribution License, which permits unrestricted use, distribution, and reproduction in any medium, provided the original author and source are credited.

\begin{abstract}
Introduction: HIV testing and counseling is associated with reduction in risk behavior. Not all persons who receive pretest counseling and testing return for posttest counseling. Hence, it is imperative to identify positive clients when they first come for testing.
\end{abstract}

Objectives: To determine demographic profile of HIV positive clients visiting our centre.

Methods: Data obtained by HIV testing of clients from January 2012 to December 2012 was analyzed. Age, gender, education, occupation and marital status were evaluated as independent variables. Analysis consisted of descriptive data of frequency tables, means, confidence intervals and multinomial logistic regression analysis.

Results: A total of 14,239 individuals were tested for HIV antibodies. Eight samples were excluded from analysis. 987(6.94\%) samples tested positive. As compared to individuals with age above 50 years, those in the age group of $35-49$ and 25-34 years had 2.6 and 1.4 times more chance of being positive respectively. Males had 1.6 times more chance of being positive than females. Non-literate had 2.2 times more chance of being positive than individuals who had education more than 10th standard. Daily wage workers from the low socio economic group had 1.5 times more chance of being positive than housewives. As compared to married individuals, divorcee/separated and widow/er had more than four times chance of being positive. A direct walk in client had 12 times more chance of being positive as compared to referred patients.

Conclusions: In our patient population, a direct walk in male client in the age group of 25 to 49 years who is not much educated, a daily wage worker and who is either separated/divorced/widow/er has a significantly higher risk of being positive. He should be tested, reported, counseled for behavioral change and practicing safe sex and linked to care and support program preferably on the same day.

Keywords: Counseling; Demographic factors; HIV; Profile; VCT

\section{Introduction}

Pretest and posttest counseling have become standard components of prevention-oriented human immunodeficiency virus (HIV) antibody testing programs. However, not all persons who receive pretest counseling and testing return for posttest counseling. It is known that HIV testing and counseling is associated with moderate decrease in sexually transmitted diseases (STD) [1]. In a meta-analysis of the effect of HIV counseling and testing on sexual risk behaviour, Weinhardt et al. found that HIV-positive individuals who underwent Voluntary Counseling and Testing (VCT) had safer sex more frequently and reduced their risk behaviors, thereby decreasing their likelihood of infecting others or becoming infected with HIV or other STD [2].

Hence, Integrated Counseling and Testing centers (ICTC) have been started across India as a key entry point for providing HIV/AIDS related services under the National AIDS Control program (NACP), Ministry of Health and Family Welfare, Government of India. Any person desirous of knowing his/her HIV status can walk-in an ICTC and get him tested without any reference. Rapid kits are being used and testing is performed as per NACO HIV testing strategy III to issue reports on the same day [3].

Mumbai is a metropolitan city which gets a lot of people coming from all over India for earning their living. The HIV epidemic has reached the general population here and it is a high prevalent area for HIV infection with reported prevalence of more than $1 \%$ in the general population [4].

Our centre is located in Mumbai, India in a public health hospital setting which mainly caters to the middle and low socio economic group. It caters to more than 50 such direct walk-in clients/patients every day who either come on their own or are referred by a physician. Considering the high workload it takes 3-4 hours for the report to be issued after posttest counseling. Most often the patients/clients do not prefer to wait and collect the report on the same day. Earlier studies have also demonstrated that only about $63 \%$ of clients return for posttest counseling [5]. Hence, it is imperative that we identify clients at increased risk of being HIV positive so as to fast track their test results and post-test counseling.

Targeted interventions in the National AIDS Control program focus on Female Sex Worker (FSW), Men who Have Sex with Men 
Citation: Ingole N, Paranjpe S, Sarkate P, Kawane U, Mody M (2014) Demographic Profile of HIV Sero Positive Clients Attending Integrated Counseling and Testing Centre, Mumbai, India. J AIDS Clin Res 5: 369. doi:10.4172/2155-6113.1000369

Page 2 of 5

(MSM), Injecting Drug User (IDU), Trans-gender, Single Male Migrants and Long Distance Truckers [4]. However, most ICTCs have received inadequate and unsatisfactory attention. Hence, this study was conducted to determine the demographic profile of HIV positive clients visiting our centre.

\section{Methods}

Institutional Ethics committee approval was obtained prior to commencement of the study. Data obtained by HIV testing of clients visiting the ICTC over a period of one year from January 2012 to December 2012 was retrospectively analyzed. Direct walk-in clients as well as referrals were included in the study. Pre-test counseling was done for all the clients. After obtaining written informed consent, demographic profile including age, gender, education, occupation and marital status was recorded. The counselor also noted down the probable route of HIV exposure. One blood sample was collected for each patient. HIV testing was performed as per NACO guidelines as per strategy III [3]. All the specimens were first screened by a dot immunoassay. Non-Reactive specimens were reported as negative. Reactive specimens were further subjected to two different supplemental rapid tests. Specimens reactive by all the three tests were reported as positive. Reports were given to the patients after post-test counseling.

Age, gender, education, occupation and marital status were evaluated as independent variables. All occupations accounting for less than $2 \%$ of the cohort were grouped as others. HIV status was the outcome. Analysis consisted of descriptive data of frequency tables, means, confidence intervals and multinomial logistic regression analysis. "R" Version 2.15.3 Copyright 2013, The R foundation for Statistical Computing was used for analysis. A P value of less than 0.05 was considered significant.

\section{Results}

A total of 14,239 individuals were tested for HIV antibodies during the study period. Eight samples were excluded from analysis (Six samples had indeterminate result, one sample was hemolysed and quantity was not sufficient for testing in case of one sample). Thus out of 14231,987 samples tested positive (6.94\%). Post-test counseling was done for 12932 (90.9\%) clients/individuals.

\begin{tabular}{|l|l|l|l|l|lr|}
\hline & $\begin{array}{l}\text { HIV } \\
\text { Positive } \\
(\%)\end{array}$ & $\begin{array}{l}\text { HIV } \\
\text { Negative } \\
(\%)\end{array}$ & $\begin{array}{l}\text { Total } \\
(\%)\end{array}$ & P value & $\begin{array}{l}\text { Odds Ratio (95\% } \\
\text { Confidence } \\
\text { Interval) }\end{array}$ \\
\hline Age in yrs & & & & & \multicolumn{3}{|l|}{} \\
\hline $0-14$ & $38(4.3)$ & $\begin{array}{l}839 \\
(95.67)\end{array}$ & $\begin{array}{l}877 \\
(6.16)\end{array}$ & 0.672 & $\begin{array}{l}1.128 \\
1.965)\end{array}$ & $(0.647-$ \\
\hline $15-24$ & $65(3.0)$ & $\begin{array}{l}2071 \\
(96.96)\end{array}$ & $\begin{array}{l}2136 \\
(15.01)\end{array}$ & 0.071 & $\begin{array}{l}0.72 \\
1.028)\end{array}$ & $(0.504-$ \\
\hline $25-34$ & $271(7.1)$ & $\begin{array}{l}3550 \\
(92.91)\end{array}$ & $\begin{array}{l}3821 \\
(26.85)\end{array}$ & 0.01 & $\begin{array}{l}1.371 \\
1.743)\end{array}$ & $(1.078-$ \\
\hline $35-49$ & $456(11.4)$ & $\begin{array}{l}3561 \\
(88.65)\end{array}$ & $\begin{array}{l}4017 \\
(28.23)\end{array}$ & $\begin{array}{l}<0.000 \\
1\end{array}$ & $\begin{array}{l}2.594 \\
3.238)\end{array}$ & $(2.079-$ \\
\hline$\geq 50$ & $157(4.6)$ & $\begin{array}{l}3223 \\
(95.36)\end{array}$ & $\begin{array}{l}3380 \\
(23.75)\end{array}$ & ref & \multicolumn{2}{|l|}{ ref } \\
\hline Gender & & & & & \multicolumn{3}{|l}{} \\
\hline
\end{tabular}

\begin{tabular}{|c|c|c|c|c|c|}
\hline Male & $617(8.0)$ & $\begin{array}{l}7106 \\
(92.01)\end{array}$ & $\begin{array}{l}7723 \\
(54.27)\end{array}$ & $\begin{array}{l}<0.000 \\
1\end{array}$ & $\begin{array}{l}1.634 \\
(1.321-2.022)\end{array}$ \\
\hline Female & $370(5.7)$ & $\begin{array}{l}6138 \\
(94.31)\end{array}$ & $\begin{array}{l}6508 \\
(45.73)\end{array}$ & ref & ref \\
\hline \multicolumn{6}{|l|}{ Education } \\
\hline Non-literate & $151(8.2)$ & $\begin{array}{l}1681 \\
(91.76)\end{array}$ & $\begin{array}{l}1832 \\
(12.87)\end{array}$ & $\begin{array}{l}<0.000 \\
1\end{array}$ & $\begin{array}{l}2.227 \\
(1.649-3.006)\end{array}$ \\
\hline $\begin{array}{l}\text { Primary } \\
\text { School }\end{array}$ & $219(6.6)$ & $\begin{array}{l}3086 \\
(93.37)\end{array}$ & $\begin{array}{l}3305 \\
(23.22)\end{array}$ & $\begin{array}{l}<0.000 \\
1\end{array}$ & $\begin{array}{l}1.713 \\
(1.314-2.231)\end{array}$ \\
\hline $\begin{array}{l}\text { Secondary } \\
\text { school }\end{array}$ & $506(7.5)$ & $\begin{array}{l}6263 \\
(92.52)\end{array}$ & $\begin{array}{l}6769 \\
(47.57)\end{array}$ & 0.004 & $\begin{array}{l}1.41 \\
(1.114-1.785)\end{array}$ \\
\hline $\begin{array}{l}\text { College \& } \\
\text { above }\end{array}$ & $111(4.8)$ & $\begin{array}{l}2214 \\
(95.23)\end{array}$ & $\begin{array}{l}2325 \\
(16.34)\end{array}$ & ref & ref \\
\hline \multicolumn{6}{|l|}{ Occupation } \\
\hline $\begin{array}{l}\text { Daily wage } \\
\text { worker }\end{array}$ & $515(10.4)$ & $\begin{array}{l}4457 \\
(89.64)\end{array}$ & $\begin{array}{l}4972 \\
(34.94)\end{array}$ & 0.001 & $\begin{array}{l}1.509 \\
(1.188-1.916)\end{array}$ \\
\hline Salaried & $119(6.8)$ & $\begin{array}{l}1621 \\
(93.16)\end{array}$ & $\begin{array}{l}1740 \\
(12.23)\end{array}$ & 0.807 & $\begin{array}{l}1.038 \\
(0.768-1.405)\end{array}$ \\
\hline Business & $21(9.8)$ & $\begin{array}{l}193 \\
(90.19)\end{array}$ & $\begin{array}{l}214 \\
(1.5)\end{array}$ & 0.138 & $\begin{array}{l}1.527 \\
(0.873-2.672)\end{array}$ \\
\hline Retired & $11(2.3)$ & $\begin{array}{l}476 \\
(97.74)\end{array}$ & $\begin{array}{l}487 \\
(3.42)\end{array}$ & 0.04 & $\begin{array}{l}0.487 \\
(0.245-0.968)\end{array}$ \\
\hline Student & $54(3.4)$ & $\begin{array}{l}1523 \\
(96.58)\end{array}$ & $\begin{array}{l}1577 \\
(11.08)\end{array}$ & 0.847 & $\begin{array}{l}0.952 \\
(0.576-1.574)\end{array}$ \\
\hline Others & $54(4.3)$ & $\begin{array}{l}696 \\
(95.74)\end{array}$ & $\begin{array}{l}727 \\
(5.11)\end{array}$ & 0.944 & $\begin{array}{l}1.016 \\
(0.651-1.585)\end{array}$ \\
\hline House-wife & $54(5.2)$ & $\begin{array}{l}4278 \\
(94.77)\end{array}$ & $\begin{array}{l}4514 \\
(31.72)\end{array}$ & ref & ref \\
\hline \multicolumn{6}{|c|}{ Marital Status } \\
\hline Single & $139(4.7)$ & $\begin{array}{l}2810 \\
(95.29)\end{array}$ & $\begin{array}{l}2949 \\
(20.72)\end{array}$ & 0.898 & $\begin{array}{l}0.983 \\
(0.756-1.278)\end{array}$ \\
\hline $\begin{array}{l}\text { Divorcee/ } \\
\text { Separated }\end{array}$ & $19(29.2)$ & $46(70.77)$ & $\begin{array}{l}65 \\
(0.46)\end{array}$ & $\begin{array}{l}<0.000 \\
1\end{array}$ & $\begin{array}{l}4.721 \\
(2.526-8.823)\end{array}$ \\
\hline Widow & $152(19.4)$ & $\begin{array}{l}630 \\
(80.56)\end{array}$ & $\begin{array}{l}782 \\
(5.5)\end{array}$ & $\begin{array}{l}<0.000 \\
1\end{array}$ & $\begin{array}{l}4.515 \\
(3.520-5.792)\end{array}$ \\
\hline Married & $677(6.5)$ & $\begin{array}{l}9758 \\
(93.51)\end{array}$ & $\begin{array}{l}10435 \\
(73.33)\end{array}$ & ref & ref \\
\hline \multicolumn{6}{|l|}{ Referral } \\
\hline $\begin{array}{l}\text { Direct walk } \\
\text { in }\end{array}$ & $786(19.7)$ & $\begin{array}{l}3211 \\
(80.34)\end{array}$ & $\begin{array}{l}3997 \\
(28.09)\end{array}$ & $\begin{array}{l}<0.000 \\
1\end{array}$ & $\begin{array}{l}12.029 \\
(10.191-14.198)\end{array}$ \\
\hline Referred & $201(2.0)$ & $\begin{array}{l}10033 \\
(98.04)\end{array}$ & $\begin{array}{l}10234 \\
(71.91)\end{array}$ & ref & ref \\
\hline
\end{tabular}

Table 1: Demographic profile of individuals attending the ICTC during the study period $(\mathrm{n}=14231)$.

Majority of the patients tested were in the age group of 35-49 years (28\%) and 25-34 years (27\%). Majority of HIV positive clients were in the age group of $35-49$ years (46.2\%) whereas only $4 \%$ were less than 14 years of age. As compared to individuals with age above 50 years, those in the age group of 35-49 years had about 2.6 times more chance 
of being positive (CI 2.079-3.238) and those in the age group of 25-34 years had 1.4 times more chance of being positive (CI 1.078-1.743) (Table 1).

The probable route of exposure in 917 (92.9\%) HIV positive individuals was unprotected heterosexual contact. The other reported routes of exposures were homosexual contact in $1(0.1 \%)$, blood transfusion in $9(0.9 \%)$, infected syringes and needles in $2(0.2 \%)$ and mother to child transmission in $36(3.65 \%)$ individuals. The probable route of exposure could not be determined in $22(2.2 \%)$ individuals $62.51 \%$ of HIV positive individuals were males $(\mathrm{P}<0.0001)$. Males had 1.6 times more chance of being positive as compared to females (CI 1.321-2.022) (Table 1).

As compared to individuals who had education more than $10^{\text {th }}$ standard, non-literate had 2.2 times more chance of being positive (CI 1.649-3.006). HIV positivity was significantly less in clients who had education above $10^{\text {th }}$ standard as compared to illiterate and those who had education up to primary and secondary school $(\mathrm{P}<0.01)($ Table 1$)$.

Majority of clients were daily wage workers in the low socio economic background (34.94\%) followed by housewives $(31.72 \%)$, salaried individuals (12.23\%) and students (11.08\%). Only $1.5 \%$ was businessmen. Majority of HIV positive clients were daily wage workers in the low socio economic background $(52.18 \%)(\mathrm{P}=0.001)$. As compared to house wives, daily wage workers had 1.5 times more chance of being positive (CI 1.188-1.916). Retired individuals had significantly low HIV positivity. $(\mathrm{P}=0.04)$ (Table 1$)$.

As per the marital status individuals were grouped into single, married, divorcee/separated and widow/er. These groups were mutually exclusive. Married clients were $73.33 \%$ whereas $20.72 \%$ were single, $0.46 \%$ were divorcee/separated from their spouse and $5.5 \%$ of individuals were widow/er. As compared to married individuals, divorcee/separated and widow/er had more than four times chance of being positive. $(\mathrm{P}<0.0001)$ (Table 1$)$.

Direct walk-in clients who came on their own for testing (client initiated testing) were $28.09 \%$ whereas $71.91 \%$ were referred by clinicians (provider initiated testing). Around $80 \%$ of HIV positive individuals were direct walk in whereas $80 \%$ of HIV negative individuals were referred $(\mathrm{P}<0.0001)$. Thus a direct walk in client has 12 times more chance of being positive as compared to referred patients (CI 10.191-14.198) (Table 1).

\section{Discussion}

HIV is a multidimensional epidemic and is affected by demographic, socio-cultural, behavioral, economic and biological factors. Urbanization has been the major contributing factor in the spread of HIV within our country. The occupants of large slums are stripped of their basic necessities of life like shelter, clean water, sanitation, health and safe environment. The life of people in such horrendous living conditions increases peoples' need for drugs, alcohol companionship and sexual satisfaction. The HIV epidemic widens and deepens poverty by its serious economic impact on individuals, households and different sectors [6]. Forty one percent of the people living with HIV are from Urban India [7].

HIV epidemic involves not only a society's capacity to deal with the epidemic and prevent exposure as well as infection; but to do so in the background of poverty. Society's potentiality to facilitating behavioral change should also be considered. In the current study, 1299 (9.1\%) reports were not picked up during the study period including positive reports. Variables independently associated with returning for HIV posttest counseling include self-reported risk behavior, sex, race or ethnicity, age, site of counseling and testing, reason for visit, and HIV sero-status [5]. Ours is a high burden center with three full time counselors. An individual counselor conducts at least 15 pre and posttest counseling sessions each per working day. This affects the quality of the counseling and may be one of the reasons for avoiding post-test counseling on part of the clients. However, as this was a retrospective analysis of data, the exact reasons of avoidance of post-test counseling by the clients could not be ascertained. Hence, it is very essential that the people who have a higher probability of being positive are identified to bring about a behavioral change and prevent further spread of infection.

HIV risk behaviors are shaped in the context of demographic factors, such as age, gender, occupation, education and marital status. These factors also make it more or less likely that individuals who engage in risky sexual or IV drug-using behavior will come into contact with persons who themselves have HIV. However, the epidemiologic data on HIV/AIDS in India has emerged primarily from the network of sentinel surveillance, ongoing testing in antenatal clinics and blood banks, research studies, reporting of AIDS cases and information generated from mortality statistics. The geographic distribution of the HIV epidemic in India is varied; and based on the prevalence of HIV infection in the low and high risk groups, various States have been categorized in high, medium and low prevalence areas [8]. Hence, it is necessary that these factors are studied in the context of predicting HIV positivity at each geographic area and center. Mumbai has consistently been a high prevalent district with positivity in general population being $>1 \%$ [8]. Our study however reported a higher HIV positivity of $6.94 \%$.

In the current study, the majority of positive patients were in the age group of 25 to 49 years which is the sexually active and economically productive age group. Considering the fact that heterosexual transmission is the most common route of transmission in the current study which is the same as reported in India [7], the high number of HIV positives in this age group is expected. However, it has been reported that about half of all new HIV infections worldwide, or approximately 6,000 per day, occur among young people aged 15-24 as despite high levels of sexual activity, young people often do not know the basic HIV/AIDS statistics and facts, which puts them at risk [9]. Even in the United States, youth aged 13 to 24 accounted for an estimated $26 \%$ of all new HIV infections [10]. Macrolevel cultural norms impact adolescents' sexual initiation timing [11]. The age of sexual initiation varies from place to place $[12,13]$ and the comparatively late initiation of adolescents sexual activity in India [14] and lesser percentage of adolescence engaging in pre marital sex [15] may be the reason for the higher age group seen in the current study. However, various studies carried out in antenatal mothers in India have reported a higher positivity in the younger age group $[16,17]$. This highlights the heterogeneity of the HIV epidemic and a need for the analysis data at local level.

A person's biological sex classification, as well as the social roles associated with each biological sex category (gender), influences other risk factors for HIV/AIDS. Cultural norms encourage men to demonstrate their masculinity by having multiple sex partners and coercing women into having sex, which increases HIV risk. Men are also much more likely than women to abuse alcohol and drugs, which increases the likelihood that they will engage in unprotected sex. Men are also more likely than women to inject drugs, exposing them to the 
risk of HIV from infected needles and syringes [18]. Married men are much more likely than married women to engage in extramarital sex, and it is more acceptable for them to do so [19]. Also, Mumbai is a metropolitan city and gets a lot of migrant workers from all over India. These people stay away from family and often indulge in high risk behavior [20]. This might be the probable reason of the significantly higher positivity seen in the males in the present study. $(\mathrm{P}<0.0001)$.

HIV is a preventable disease and primordial prevention can bring down the transmission. Socioeconomic status indicates people's standing in society and is usually measured by their income, occupation, or educational attainment. Socioeconomic status is one of the most powerful predictors of sickness and health [21]. People with lower socioeconomic status are more likely to contract and transmit HIV/AIDS, perhaps because they have less knowledge about HIV/ AIDS, are surrounded by people who are more likely to have HIV/ AIDS, and are more likely to use drugs and practice unsafe sex to escape from stress [22]. Increased awareness and knowledge about the disease is very essential to protect self from the disease by using appropriate precautions. School education has been known to play a significant role in preventing early sexual initiation and risky sexual behavior [23]. The significantly higher positivity amongst patients/ clients with lower education and daily wage workers from low socio economic background in the current study supports these. In contrast the retired people belonging to the older age group had a significantly lower risk of being positive (Table 1).

Compared to married individuals, divorced, separated and widowed individuals had a significantly higher risk of being positive. In contrast, the unmarried individuals had a lower risk of being positive. This may be due to the fact that as per the socio-cultural factors in India especially in the middle and low class population who form the majority of our individuals, pre and extra marital sex is still considered a taboo. Also, Adult AIDS mortality is associated with increased risk of household dissolution [24] leading to divorced, separated and widowed clients/patients.

Traditional VCT (also called client-initiated VCT) involves individuals actively seeking HIV testing and counseling at a facility that offers these services [25-27]. Routine offer of HIV counseling and testing (also known as provider-initiated VCT) refers to HIV testing and counseling which is recommended by healthcare providers to persons attending healthcare facilities as a standard component of medical care $[27,28]$. According to the recent WHO/UNAIDS guidelines an HIV test is recommended for all patients, irrespective of the epidemic setting, who's clinical presentation, might result from underlying HIV infection, as a standard part of medical care for all patients attending health facilities in generalized HIV epidemics and more selectively in concentrated and low-level epidemics. The purpose of such testing and counseling is to enable specific clinical decisions to be made andor specific medical services to be provided that would not be possible without the knowledge of the person's HIV status [29].

Our ICTC is situated in a public hospital which caters mainly to the middle and low socio-economic group. The clients visiting the ICTC either come voluntarily (client initiated) or are referred by the physician (provider initiated). The client initiated testing had a significantly higher positivity compared to the provider initiated testing $(\mathrm{P}<0.0001)$ and a 12 times more chance of being positive. This may be due to the fact that these clients are the one who usually indulge in high risk behavior and come voluntarily for testing. Whereas the patients referred by clinicians usually have some other complaints and are tested for HIV in the course of their treatment.
Hence, in our patient population, a direct walk in male client in the age group of 25 to 49 years who is not much educated, is a daily wage worker from a low socio economic background and who is either separated/divorced/widow/er has a significantly higher risk of being positive. He should be identified, counseled for behavioral change and practicing safe sex and linked to care and support program on the day he comes for testing.

This study had certain limitations. This was a cross-sectional and center-based study. Therefore, results from analysis cannot be generalized. Also, the study was based on the assumption that the participants responded honestly and to the best of their knowledge and ability. Other limitation includes the fact that no information was collected on sexual behaviors such as number of sex partners, condom use or STIs/STD. These would have helped to assess the risk factors further.

The changing face of the HIV/AIDS epidemic has resulted in new opportunities to increase access to voluntary HIV counseling and testing. As access to HIV treatment becomes more widely available, the need for identification and linking of positive patients to care and support services would become even greater. A lot of efforts are being made at the national level regarding the same. However, it is also essential to make efforts at the micro level. Considering the significantly high positivity seen in client initiated testing, further enlightenment campaigns at local level are required. Also, the data generated at each center should be analyzed periodically to understand the demographic profile and use the knowledge in better management of the epidemic.

\section{References}

1. Otten MW Jr, Zaidi AA, Wroten JE, Witte JJ, Peterman TA (1993) Changes in sexually transmitted disease rates after HIV testing and posttest counseling, Miami, 1988 to 1989. Am J Public Health 83: 529-533.

2. Weinhardt LS, Carey MP, Johnson BT, Bickham NL (1999) Effects of HIV counseling and testing on sexual risk behavior: a meta-analytic review of published research,1985-1997. Am J Public Health 89: 1397-1405.

3. Guidelines on HIV Testing (2007) National AIDS Control Organisation, Ministry of Health and Family Welfare, Government of India.

4. State fact sheets (2012) National AIDS Control Organisation, Ministry of Health and Family Welfare, Government of India.

5. Valdiserri RO, Moore M, Gerber AR, Campbell CH Jr, Dillon BA, et al. (1993) A study of clients returning for counseling after HIV testing: implications for improving rates of return. Public Health Rep 108: 12-18.

6. How are Urbanization, poverty and HIV related? Ministry of Housing and Urban Poverty Alleviation Government of India.

7. Understanding HIV in India-the Country. Profile. Ministry of Housing and Urban Poverty Alleviation, Government of India.

8. Godbole S, Mehendale S (2005) HIV/AIDS epidemic in India: risk factors, risk behaviour \& strategies for prevention \& control. Indian J Med Res 121: 356-368.

9. HIV/AIDS and Adolescents. UNFPA State of World population.

10. Mehta P, Antao V, Kaye W, Sanchez M, Williamson D, et al. (2014) Prevalence of amyotrophic lateral sclerosis - United States, 2010-2011. MMWR Surveill Summ 63: 1-14.

11. Madkour AS, de Looze M, Ma P, Halpern CT, Farhat T, et al. (2014) Macro-level age norms for the timing of sexual initiation and adolescents' early sexual initiation in 17 European countries. J Adolesc Health 55: $114-121$. 
Citation: Ingole N, Paranjpe S, Sarkate P, Kawane U, Mody M (2014) Demographic Profile of HIV Sero Positive Clients Attending Integrated Counseling and Testing Centre, Mumbai, India. J AIDS Clin Res 5: 369. doi:10.4172/2155-6113.1000369

Page 5 of 5

12. Olugbenga-Bello AI, Adebimpe WO, Akande RO, Oke OS (2014) Health risk behaviors and sexual initiation among in-school adolescents in rural communities in southwestern Nigeria. Int J Adolesc Med Health.

13. Shiferaw Y, Alemu A, Assefa A, Tesfaye B, Gibermedhin E, et al. (2014) Perception of risk of HIV and sexual risk behaviors among University students: implication for planning interventions. BMC Res Notes 7: 162.

14. Potdar R, Mmari K (2011) Factors influencing sexual initiation, multiple partners and condom use among male slum youth in Pune, India. Glob Public Health 6: 843-858.

15. Santhya KG, Acharya R, Jejeebhoy SJ, Ram U (2011) Timing of first sex before marriage and its correlates: evidence from India. Cult Health Sex 13: 327-341.

16. Gupta S, Gupta R, Singh S (2007) Seroprevalence of HIV in pregnant women in North India: a tertiary care hospital based study. BMC Infect Dis 7: 133.

17. Giri PA, Bangal VB, Phalke DB. (2012) Prevalence of HIV among rural pregnant women attending antenatal clinics at pravara rural hospital, Loni, Maharashtra, India. International Journal of Health and Allied sciences 1: 13-15.

18. The HIV/AIDS pandemic and its gender implications (2000) Report of the Expert Group Meeting Windhoek, Namibia, 13 - 17 November 2000. United Nations Division for the Advancement of Women World Health Organization (WHO) and Joint United Nations Programme on HIV/ AIDS (UNAIDS).

19. Smith DJ (2007) Modern marriage, men's extramarital sex, and HIV risk in southeastern Nigeria. Am J Public Health 97: 997-1005.

20. Saggurti N, Mahapatra B, Sabarwal S, Ghosh S, Johri A (2012) Male outmigration: a factor for the spread of HIV infection among married men and women in rural India. PLoS One 7: e43222.
21. Marmot M (2005) Social determinants of health inequalities. Lancet 365: 1099-1104.

22. Lim TW, Frangakis C, Latkin C, Ha TV, Minh NL, et al. (2014) Community-level income inequality and HIV prevalence among persons who inject drugs in Thai Nguyen, Vietnam. PLoS One 9: e90723.

23. Rees CA, Long KN, Gray B, West JH, Chanani S, et al. (2012) Educating for the future: adolescent girls' health and education in West Bengal, India. Int J Adolesc Med Health 24: 321-327.

24. Hosegood V (2009) The demographic impact of HIV and AIDS across the family and household life-cycle: implications for efforts to strengthen families in sub-Saharan Africa. AIDS Care 21: 13-21.

25. Fylkesnes K, Siziya S (2004) A randomized trial on acceptability of voluntary HIV counselling and testing. Trop Med Int Health 9: 566-572.

26. Creek TL, Alwano MG, Molosiwa RR, Roels TH, Kenyon TA, et al. (2006) Botswana's Tebelopele voluntary HIV counseling and testing network: use and client risk factors for HIV infection, 2000-2004. J Acquir Immune Defic Syndr 43: 210-218.

27. Operational Guidelines of Integrated Counselling and Testing centers (2007) National AIDS Control Organisation, Ministry of Health and Family Welfare, Government of India.

28. Weiser SD, Heisler M, Leiter K, Percy-de Korte F, Tlou S, et al. (2006) Routine HIV testing in Botswana: a population-based study on attitudes, practices, and human rights concerns. PLoS Med 3: e261.

29. Guidance on provider-initiated HIV testing and counselling in health facilities. WHO / UNAIDS 2007. 